\title{
Botrytis fabae and Bean common mosaic virus (BCMV) are the most common diseases of Faba bean (Vicia faba L.) in TRNC*
}

\author{
Ayșegül ÇOLAK ATES ${ }^{1}$, Hakan FIDAN², Nihat YILMAZ ${ }^{3}$, Ayda KONUKSAL ${ }^{4}$
}

\author{
${ }^{1}$ Republic of Turkey Ministry of Food Agriculture and Livestock / Biological Control Research Institute, ADANA \\ ${ }^{2}$ Akdeniz University, Faculty of Agriculture, Plant Protection, ANTALYA \\ ${ }^{3}$ Erciyes University, Safiye Cikrıkcioglu Vocational College, KAYSERI \\ ${ }^{4}$ Agriculture. Research. Institute. Lefkosa, NORTHERN CYPRUS
}

*This paper is presented in "The V. Plant Protection Congress (February 3-5, 2014 in Antalya/Turkey) and published as an abstract.

Alınış tarihi: 27 Mart 2017, Kabul tarihi: 20 Temmuz 2017

Sorumlu yazar: Ayșegül ÇOLAK ATEŞ, e-posta:aysegulcolak@hotmail.com

\begin{abstract}
Surveys were conducted on the fields of faba bean culture in Turkish republic of North Cyprus (TRNC) during 2011-2013 indicated that Botrytis fabae and Bean common mosaic virus (BCMV) are the diseases that cause crop loss at economic level. During the field surveys 117 infected plants that have the symptoms of both diseases were collected from 38 different locations. Symptomatologic, morphologic and classic tests indicated that 96 of the faba bean samples had Chocolate spot disease caused by Botrytis fabae and the conidia lengths have been measured between 12.7-22.4 x 9.4-17.8 microns. Faba bean samples with virus symptoms that were collected from 38 locations. All samples were infected by Bean common mosaic potyvirus (BCMV) serologically (DAS-ELISA) The 850 bp section of BCMV isolates coat protein was increased using RT-PCR method. This section was sequenced directly using ClonJet and characterization was determined. According to Blast obtained from sequences $98 \%$ and $96 \%$ resemblances with Mexican and Columbian isolates have been found.
\end{abstract}

Key words: Faba bean, Botrytis fabae, Bean common mosaic virüs, PCR
KKTC bakla yetiștiriciliğinde en yaygın hastalıklar Botrytis fabae ve bean common mozaik virüs

Öz

KKTC'de bakla (Vicia fabae L.) yetiştiriciliği yapılan alanlarda 2011-2013 yılları arasında yapılan sürveyler de ekonomik düzeyde verim kaybına neden en önemli hastalıklar Botrytis fabae ve Bean common mozaik virüs (BCMV) olarak belirlenmiștir. Bakla yetiştirilen 38 farklı lokasyonda yapılan surveyde her iki etmenin simptomlarını gösteren 117 enfekteli bitki toplanmıştır. Simptomatolojik, morfolojik ve klasik testleme sonucunda 96 adet bakla örneğinin Botrytis fabae'nın neden olduğu çikolata benek hastalığı olduğu ve konidi uzunluklarının 12.7-22.4 x 9.4-17.8 mikron arasında olduğu tespit edilmiştir. Virüs simptomu gösteren bakla örnekleri 38 lokasyondan toplanmıș, toplanan örneklerin tamamında serolojik olarak (DAS-ELISA) Bean common mosaic potyvirus (BCMV) ile bulaşık bulunmuştur. Serolojik olarak tespit edilen BCMV izolatlarının kılıf proteinine özgü 850 bp bölge, RTPCR yöntemi kullanarak çoğaltılmıștır. Çoğaltılan bu bölge direkt Clonjet kullanılarak sekanslanmış ve karekterizasyonu yapılmıştır. Elde edilen sekanslardan yapılan Blast sonucunda \% 98 ve 96 oranında Meksika ve Kolombiya izolatları ile benzerlik göstermektedir.

Anahtar kelimeler: Bakla, Botrytis fabae, Bean common mozaik virus, PCR, bitki hastalıkları, Kuzey Kibris 


\section{Introduction}

Faba beans that have a significant place in human nutrition both for fresh and dry consumption is a highly valuable source of protein. Dried bean with its $20-36 \%$ protein content is considered as an important part of both human and animal diet. Protein content of green faba beans is $5-7 \%$, but at earlier stages is around 3-10\%. In early ripening varieties protein content is much less than the late ripening varieties. As with all legumes faba is a good rotation plant to increase soil fertility.

Faba production of the world is 3.398 .330 tons. China has the biggest producer with 1.400 .000 tons which is followed by Australia with 297.500 tons (Anonymous, 2013). In Turkish Republic of North Cyprus (TRNC) yearly faba bean cultivation area is approximately 70 hectares and from this cultivation 65 tons dry faba beans and 580 ton green faba beans are produced. According to 2011 productiones $77 \%$ of the yield was obtained from Güzelyurt (Omorpho) region which is followed by Gazimağusa (Famagusta) region with 10\% (Anonymous, 2012).

One of the most important diseases in faba bean cultivation in terms of economic losses is Chocolate spot disease caused by Botrytis fabae which has been reported in many other places of the world Harrison, 1988; Koike, 1998; Rahmanet alet al., 2002; Yehia et al.,2004). Chocolate spot disease can be seen as small reddish brown circular or oval spots on stems, leaves, flowers and seeds of the faba plants (Yu, 1945; Harrison, 1988). Yield loss caused by the epidemics of this disease has been reported to reach as high as $50-100 \%$ in South Australia, Ethiopia, Egypt, England and China (Davidson et al., 2007; Rhaiemi et al., 2002; El- Sayed et al., 2011; AboHegazy et al., 2012). In addition to the yield loss due to infected plants with $B$. fabae decreased seed quality as result of this disease has become another serious issue to deal with.

Virus diseases for which no chemical solution exists there is great impact on faba production in terms of restricting the amount to be consumed by every household regardless the income levels. Although it may change depending on the region and climatic conditions the most frequently seen virus disease is caused by common mosaic potyvirus (BCMV). This virus can be carried by pests such as Acyrthosiphon pisum, Aphis craccivora, A. fabae and Myzus persicae in non-persistent manner, or mechanically by plant sap, agricultural equipment, seeds and pollens. Transfer of the disease by pollens and seeds increases epidemics, thus allows significance yield losses of BCMV disease (Biddle and Cattlin 2007).

According to various researches carried in TRNC, in addition to BCMV some other disease causing viruses are also determined (Açıkgöz, 1984; Fidan and Yorgancı 1990; Lisa et al ., 1994; Güzel and ArlıSökmen 2003; Kılıç and Yardımcı 2014), these are Bean common mosaic necrosis virus (BCMNV) (Güzel ve Arlı-Sökmen 2003; Bhadramurthy and Bhat 2009), Bean yellow mosaic virus (BYMV) (Açlkgöz, 1984; Lisa et al ., 1994), Cowpea aphid borne mosaic virus (CABMV) (Yılmaz and Özaslan 1987), Cucumber mosaic virus (CMV) (Güzel and Arlı-Sökmen 2003), Tobacco black ring virus (TRRV) (Gümüş et al., 2001) and Alfalfa mosaic virus (AMV) (Güzel and Arlı-Sökmen, 2003). BCMV and BCMNV have similar symptoms with some minor differences, and they are the most frequently seen virus diseases of faba in the world wide. Their symptoms appear as mosaic, dwarfing, leaf curling and chlorosis. Another symptom is systemic necrosis. This symptom is also named as top necrosis or black root (Cooper and Jones 1983). Top necrosis occurs with the advance of vascular necrosis resulting from hypersensitive reactions.

Aims of the research to find solution disease problems that seriously restrict faba been production which is widely consumed in TRNC and also to find answers relevant complaints of the farmers. Additionally, the project also aims to define the prevalence of Botrytis fabae and Bean common mosaic virus (BCMV) which are the most widely problem causing disease agents in the region.

\section{Materials and Methods}

In TRNC between 2011-2013 samples of faba beans (Vicia fabae L.) were taken from 38 different locations; 14 from Güzelyurt (Omorpho), 12 from Gazimağusa (Famagusta), 5 from Girne (Krynea), 4 from Iskele (Trikomo) and 3 from Lefkoşa (Nicosea). According to 2012 data of TRNC the amount of green faba bean cultivation area is $690.41 \mathrm{da}$. The distribution of this cultivation area is as follows: Güzelyurt $462.95 \mathrm{da}$, Girne $113.73 \mathrm{da}$, Gazimağusa $64.22 \mathrm{da}$, Iskele $45.5 \mathrm{da}$ and Lefkoşa $4.01 \mathrm{da}$. Keeping the total area of cultivation in mind samples of faba bean plants were taken from a total of $502.8 \mathrm{da}$ area which represent $72,8 \%$ of the total cultivation area of 690.41da (Bora and Karaca 1970). 
In order to determine the prevalance on sampling fields for both of the diseases any bean field showing the symptoms of one of the diseases on a single plant is considered as being infected by that disease. To isolate the agents of both diseases samples were labelled and stored at $+4^{\circ} \mathrm{C}$.

Aproximately 2-3 $\mathrm{mm}$ large pieces of the infected parts of the leaves and stems showing the symptoms of Botrtyis fabae (reddish dark brown spots) of the samples taken from various cultivation areas are kept for 2-3 minutes in $0.5 \%$ sodium hypochlorite (NaOCI) in a sterile container for surface sterilization. After that, they are placed in $9.0 \mathrm{~cm}$ petri dish containing Potatoes Dextrose Agar (PDA) and kept at $20 \pm 20 \mathrm{C}$ for 10 days for incubation. Following incubation isolates were re-isolated and both morphologic and macroscopic features (conidia length, shape; sclera color, shape and length) of 2 isolates from each of sample locations are identified in accordance with Morgan, (1971) and Yu, (1945).

Total 117 faba bean plant samples with virus symptoms taken from 38 locations are brought into the laboratory using cold chain. DAS-ELISA method was used serologically on all the samples. DAS-ELISA method implemented according to the protocol recommended and using antiserum provided by the firm BIOREBA showed that all of the 117 samples were infected by BCMV. The samples were tested for Bean common mosaic necrosis virus (BCMNV) and they are found to be clean.

A $100 \mathrm{mg}$ from the young leaves of the DAS-ELISA positive, in other words infected plant sample was for RNA isolation using Thermo Scientific GeneJET RNA Purification Kit. The purity and amounts of the obtained RNAs were adjusted using MaestroNano Micro-Volume Spectrophotometre and their RTPCRs conducted. RT-PCRs were done using Thermo Scientific Verso 1-Step RT-PCR Kit Reddy Mix at $50 \mathrm{oC}$ binding temperature and $50 \mu \mathrm{l}$ volume. Increasing the $850 \mathrm{bp}$ section of the coat protein of BCMV was done using the primers of BCMVF GGATGCGGAGAATCTGTG and BCMVFGATTGACGTCCCTTGCAG (Bhadramurthy and Bhat 2009). The obtained PCR products were progressed in $1.5 \%$ agarose gel and after coloring with ethidium bromide monitored under UV transilluminator. For the second verification of the samples $10 \mu \mathrm{l}$ was used and the remaining $40 \mu \mathrm{l}$ was sent to GENOKS (Molecular Biotecnology Corporation, Ankara/Turkey) for DNA serial analysis in accordance with the agreement of service purchasing. The comparision of the obtained sekans were carried by NCBI (National Center for Biotechnology Information) using BLAST (Basic Local Alignment Search Tool) software. For the family tree MEGA5 (Molecular Evolutionary Genetics Analysis) software was used.

\section{Results and Discussion}

Economically significant infected areas and their infection percentages were obtained in table 1 for TRNC's surveys areas.

The results of observations and sampling carried on 117 fields of faba bean cultivation sides considering to 520.8 da which total survey area. Studies unveiled that 96 of the fields, among total of 393.2 da were infected by Botrytis fabae. According to these results the prevalence of the disease in terms of number of infected fields was $82.1 \%$, whereas in terms of surface area $78.2 \%$. As it can be seen on Table 1 , $259.1 \mathrm{da}(75.9 \%)$ of the cultivation sites of Güzelyurt county which is the biggest faba bean producer found to be infected by Botrytis fabae (Figure 2).

Data related to the morphologic and macroscopic features (conidi lenghts, sclerot color, shape and lengths of two isolates taken from each of the faba bean cultivation sites of Güzelyurt, Gazimağusa, Girne, İskele and Lefkoşa counties are given in Table 2. Conidi lengths of Chocolate spot disease caused by Botrytis fabae are found to be 12.7-22.4 x 9.4-17.8 micron with an ovoid- elliptic shape; sclerot lenghts are found to be 1.0-4.9 x 0.3-3.2 mm with irregular shape and black color.

The results of DAS-ELISA conducted on 117 samples with mosaic dwarfing taken from 38 faba bean cultivation sites showed that all of them were infected by BCMV (Figure3). In order to find out if a mix infection existed caused by co-existence of Bean common mosaic necrosis virus (BCMNV) which has similar syptoms, all the samples were also tested with DAS-ELISA method against BCMNV. tThey were found to be clean. Intense aphid populations were observed on the samples collected and brought to laboratory in alcohol (Figure 4). Half of the aphids were used for identification and the other half for RNA isolation. The samples were aphids were identified as Aphis fabae (Scopoli) (Aphidoidea (Hemiptera) Taxonomy) by Dr. Işıl Özdemir DASELISA did not indicate any virus in aphids, but results of RT-PCR did indicated bands at $850 \mathrm{bp}$ which is specific to BCMV. 
Table 1. Results of Botrytis fabae survey conducted on faba bean cultivation fields (2011-2013)

\begin{tabular}{|c|c|c|c|c|c|c|c|}
\hline \multirow{2}{*}{\multicolumn{2}{|c|}{ County/district }} & \multirow{2}{*}{$\begin{array}{l}\text { Number of } \\
\text { Surveyed } \\
\text { areas }\end{array}$} & \multicolumn{2}{|c|}{$\begin{array}{c}\text { Number and } \\
\text { percentage of infected } \\
\text { areas } \\
\end{array}$} & \multirow[t]{2}{*}{$\begin{array}{l}\text { Surveyed } \\
\text { area (da) }\end{array}$} & \multicolumn{2}{|c|}{ Infected area ( $\mathrm{da}$ ) and percentage } \\
\hline & & & Amount & $\%$ & & da & $\%$ \\
\hline \multirow{14}{*}{ Güzelyurt } & Yeșilırmak & 9 & 7 & 77.8 & 80.9 & 65.8 & 81.3 \\
\hline & Yeşilyurt & 8 & 6 & 75.0 & 29.4 & 27.6 & 93.8 \\
\hline & Yedidalga & 5 & 3 & 75.0 & 56.7 & 43.1 & 76.0 \\
\hline & Erenköy & 3 & 3 & 100.0 & 16.7 & 10.7 & 64.1 \\
\hline & Aydınköy & 4 & 3 & 75.0 & 46.8 & 29.7 & 63.5 \\
\hline & Güneşköy & 1 & 1 & 100.0 & 4.7 & 4.7 & 100 \\
\hline & Bağlıköy & 3 & 2 & 66.7 & 7.5 & 2.7 & 36 \\
\hline & Akçay & 2 & 1 & 50.0 & 2.7 & 1.3 & 48.1 \\
\hline & Bostancl & 6 & 5 & 83.3 & 42.9 & 32.4 & 75.5 \\
\hline & Doğancı & 5 & 4 & 80.0 & 11.4 & 9.6 & 84.2 \\
\hline & Şirinköy & 3 & 2 & 66.7 & 8 & 5.4 & 67.5 \\
\hline & Gaziveren & 1 & 1 & 100.0 & 5.3 & 5.3 & 100 \\
\hline & Cengizköy & 2 & 2 & 100.0 & 19.4 & 16.1 & 82.9 \\
\hline & Zümrütköy & 3 & 2 & 66.7 & 8.7 & 4.7 & 54.0 \\
\hline Total of pr & ce or county & 52 & 42 & 80.8 & 341.1 & 259.1 & 75.9 \\
\hline \multirow{12}{*}{ Gazimağusa } & Beyarmudu & 5 & 4 & 80.0 & 15.4 & 12 & 77.9 \\
\hline & Vadili & 4 & 4 & 100.0 & 10 & 10 & 100 \\
\hline & Akdoğan & 2 & 2 & 100.0 & 3.3 & 3.3 & 100 \\
\hline & Akova & 1 & 1 & 100.0 & 0.7 & 0.7 & 100 \\
\hline & Esenköy & 3 & 3 & 100.0 & 8.7 & 8.7 & 100 \\
\hline & Ergazi & 2 & 1 & 50.0 & 2.6 & 2 & 76.9 \\
\hline & İnönü & 2 & 2 & 100.0 & 3.3 & 3.3 & 100 \\
\hline & Çayönü & 2 & 2 & 100.0 & 2 & 2 & 100 \\
\hline & Tatlısu & 4 & 3 & 75.0 & 11.4 & 9 & 78.9 \\
\hline & Çınarlı & 3 & 2 & 66.7 & 2 & 1.5 & 75 \\
\hline & Güvercinlik & 1 & 1 & 100.0 & 0.7 & 0.7 & 100 \\
\hline & Yeniboğaziçi & 2 & 2 & 100.0 & 1.3 & 1.3 & 100 \\
\hline Total of pr & ce or county & 31 & 27 & 87.1 & 61.4 & 54.5 & 88.8 \\
\hline \multirow{5}{*}{ Girne } & Center & 4 & 3 & 75.0 & 28.6 & 20.6 & 72.0 \\
\hline & Lapta & 6 & 4 & 66.7 & 16.7 & 12 & 71.8 \\
\hline & Tepebaşı & 5 & 4 & 80.0 & 6 & 6 & 100 \\
\hline & Çatalköy & 2 & 2 & 100.0 & 8.7 & 8.7 & 100 \\
\hline & Alsancak & 7 & 6 & 85.7 & 11.4 & 11.4 & 100 \\
\hline Total of pr & ce or county & 24 & 19 & 79.2 & 71.4 & 58.7 & 82.2 \\
\hline \multirow{4}{*}{ İskele } & Büyükkonuk & 3 & 2 & 66.7 & 6 & 4 & 66.6 \\
\hline & Yenierenköy & 1 & 1 & 100.0 & 4.7 & 4.7 & 100 \\
\hline & Yeşilköy & 1 & 1 & 100.0 & 7.4 & 7.4 & 100 \\
\hline & Karpaz & 2 & 1 & 50.0 & 8 & 2 & 25 \\
\hline Total of pr & ce or county & 7 & 5 & 71.4 & 26.1 & 18.1 & 69.3 \\
\hline \multirow{3}{*}{ Lefkoşa } & Center & 1 & 1 & 100.0 & 0.7 & 0.7 & 100 \\
\hline & Beyköy & 1 & 1 & 100.0 & 1.4 & 1.4 & 100 \\
\hline & Yeniceköy & 1 & 1 & 100.0 & 0.7 & 0.7 & 100 \\
\hline Total of pr & ce or county & 3 & 3 & 100.0 & 2.8 & 2.8 & 100 \\
\hline Grand tota & d percentage & 117 & 96 & 82.1 & 502.8 & 393.2 & 78.2 \\
\hline
\end{tabular}

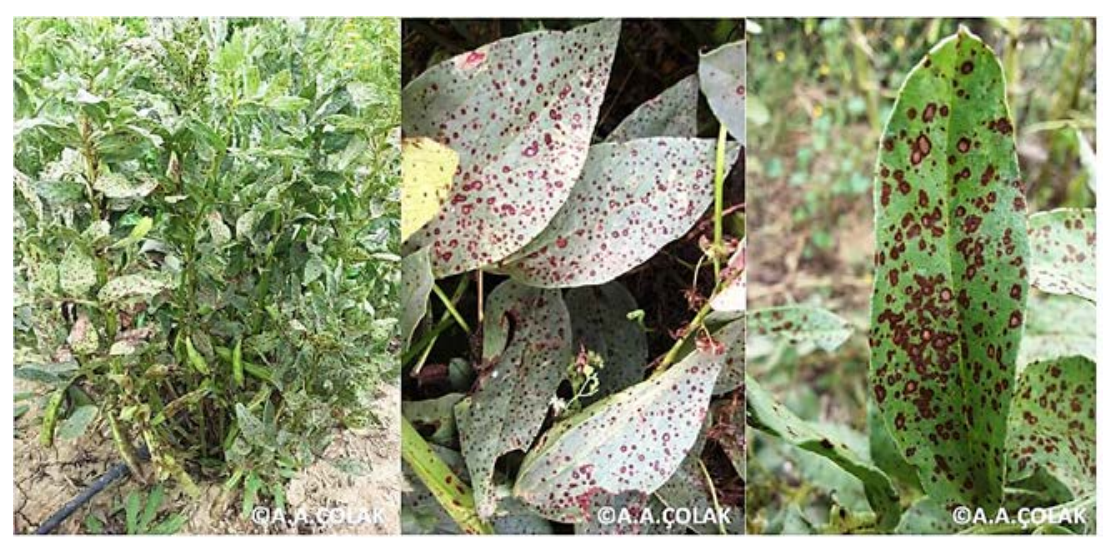

Figure 1. Small reddish brown circular or oval spots of Botrytis fabae on faba bean plant and leaves. 


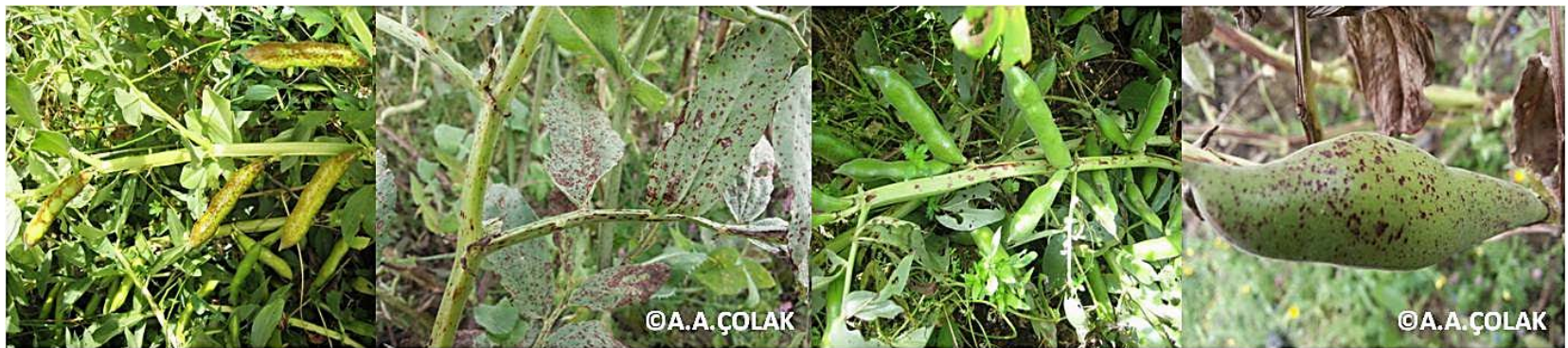

Figure 2. Botrytis fabae, small reddish brown circular symptoms on faba fruits and stems.

Table 2. Morphologic features of Botrytis fabae isolates taken from different counties of TRNC

\begin{tabular}{|c|c|c|c|c|c|}
\hline \multirow{2}{*}{ Isolate } & \multicolumn{2}{|c|}{ Conidi } & \multicolumn{3}{|c|}{ Sclerot } \\
\hline & Lenght $(\mu \mathrm{m})$ & Shape & Color & Shape & Length (mm) \\
\hline GZ-1 & $12.4-20.2 \times 10.2-17.8$ & Ovoid-elliptic & Black & Elliptic-irregular & $1.0-3.5 \times 0.4-3.2$ \\
\hline GZ-2 & $12.7-22.2 \times 10.0-17.2$ & Ovoid-elliptic & Black & Elliptic-irregular & $0.9-3.9 \times 0.5-3.0$ \\
\hline GM-1 & $14.6-21.4 \times 9.4-15.4$ & Ovoid-elliptic & Black & Elliptic-irregular & $1.0-3.6 \times 0.3-3.1$ \\
\hline GM-2 & $12.9-22.4 \times 9.8-16.6$ & Ovoid-elliptic & Black & Elliptic-irregular & $1.0-4.4 \times 0.5-2.6$ \\
\hline GR-1 & $12.6-21.8 \times 10.4-15.9$ & Ovoid-elliptic & Black & Elliptic-irregular & $1.0-4.9 \times 0.3-3.0$ \\
\hline GR-2 & $14.2-20.8 \times 10.2-17.8$ & Ovoid-elliptic & Black & Elliptic-irregular & $0.8-3.5 \times 0.6-3.0$ \\
\hline İS-1 & $12.4-21.6 \times 10.1-15.2$ & Ovoid-elliptic & Black & Elliptic-irregular & $0.6-3.4 \times 0.5-3.2$ \\
\hline İS-2 & $12.1-22.2 \times 9.8-16.8$ & Ovoid-elliptic & Black & Elliptic-irregular & $1.0-4.1 \times 0.5-3.0$ \\
\hline LF-1 & $15.4-20.4 \times 10.5-17.2$ & Ovoid-elliptic & Black & Elliptic-irregular & $0.8-4.8 \times 0.4-3.1$ \\
\hline LF-2 & $12.0-22.6 \times 9.6-17.0$ & Ovoid-elliptic & Black & Elliptic-irregular & $0.9-4.0 \times 0.6-2.8$ \\
\hline
\end{tabular}

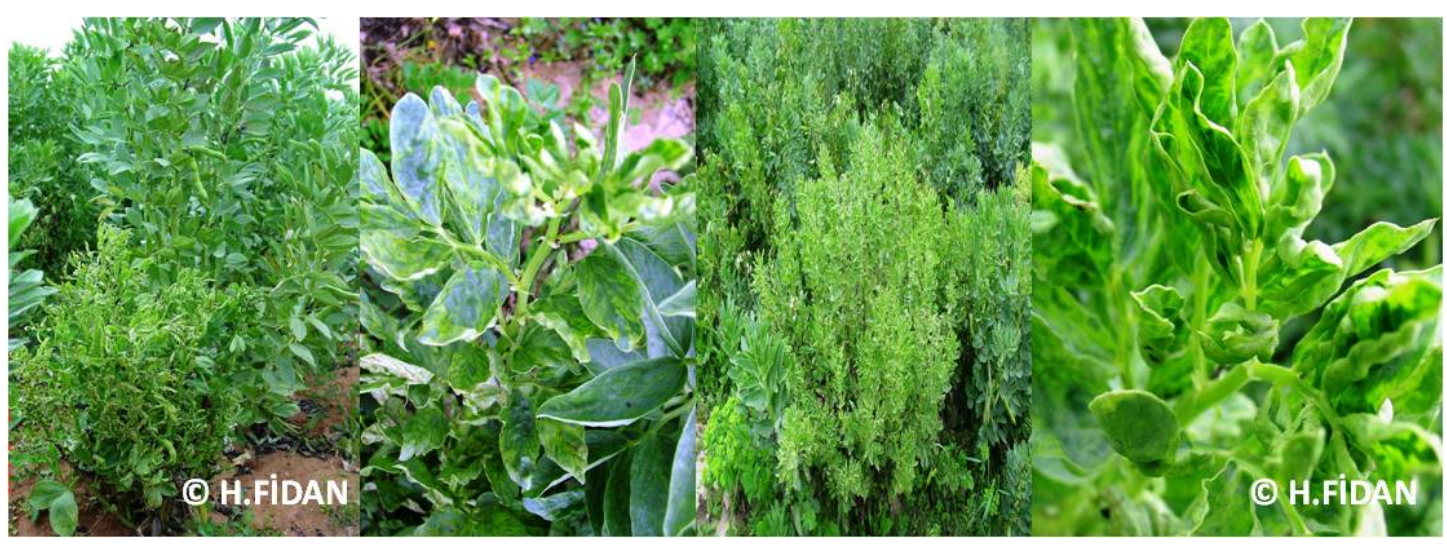

Figure 3. Mosaic, dwarfing, leaf curling and chlorosis symptoms of Bean common mosaic virus on faba bean leaves.

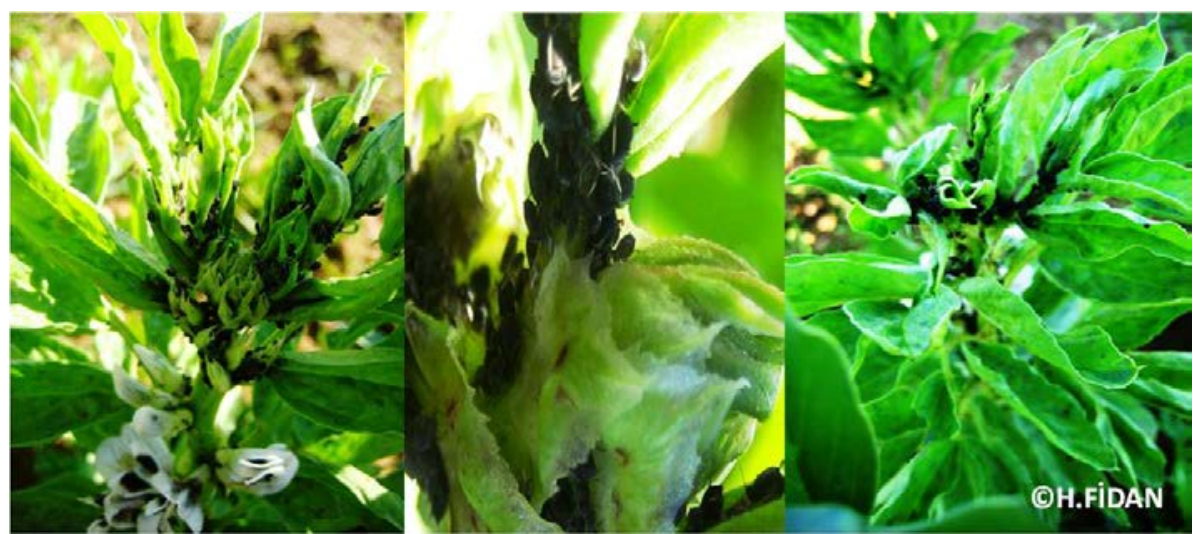

Figure 4. Faba bean plant infected by BCMV and the virus vector Aphis fabae (Scopoli) in Güzelyurt. 


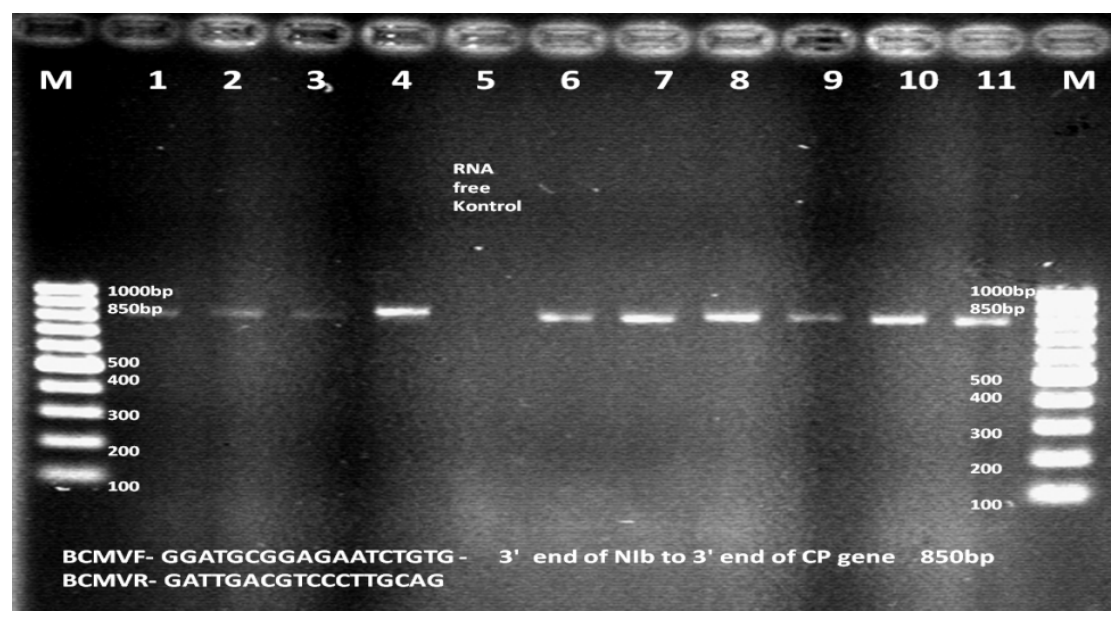

Figure 5. Agarose gel image of the section which is increased in BCMV specific 850bp. M 100 bp standart DNA ladder, 1,; Güzelyurt county faba bean plant 2; Aphis fabae samples taken from Güzelyurt Region 3,4; Gazimagusa County, 5, Health Control, 6,7; Girne County, 8,9; LefkoşaCounty 10-11 Karpaz County.

From the DAS-ELISA positive samples 10 samples are selected from each county for RT-PCR verification. DAS-ELISA results of 50 samples are verified by RT-PCR method (Figure 5). For the sequences obtained from these isolates Blas is done at NCBI with the entry number lcl|Query_135913 and the family tree prepared. From each of the 5 counties of TRNC two isolates were selected (Figure 3). As a result of direct sequencing those isolate showed 94-99\% resemblance to South American isolates, and replaced in the same group with Columbian and Mexican isolates (gb|L11890|, gb|DQ666332|) (Figure 6).

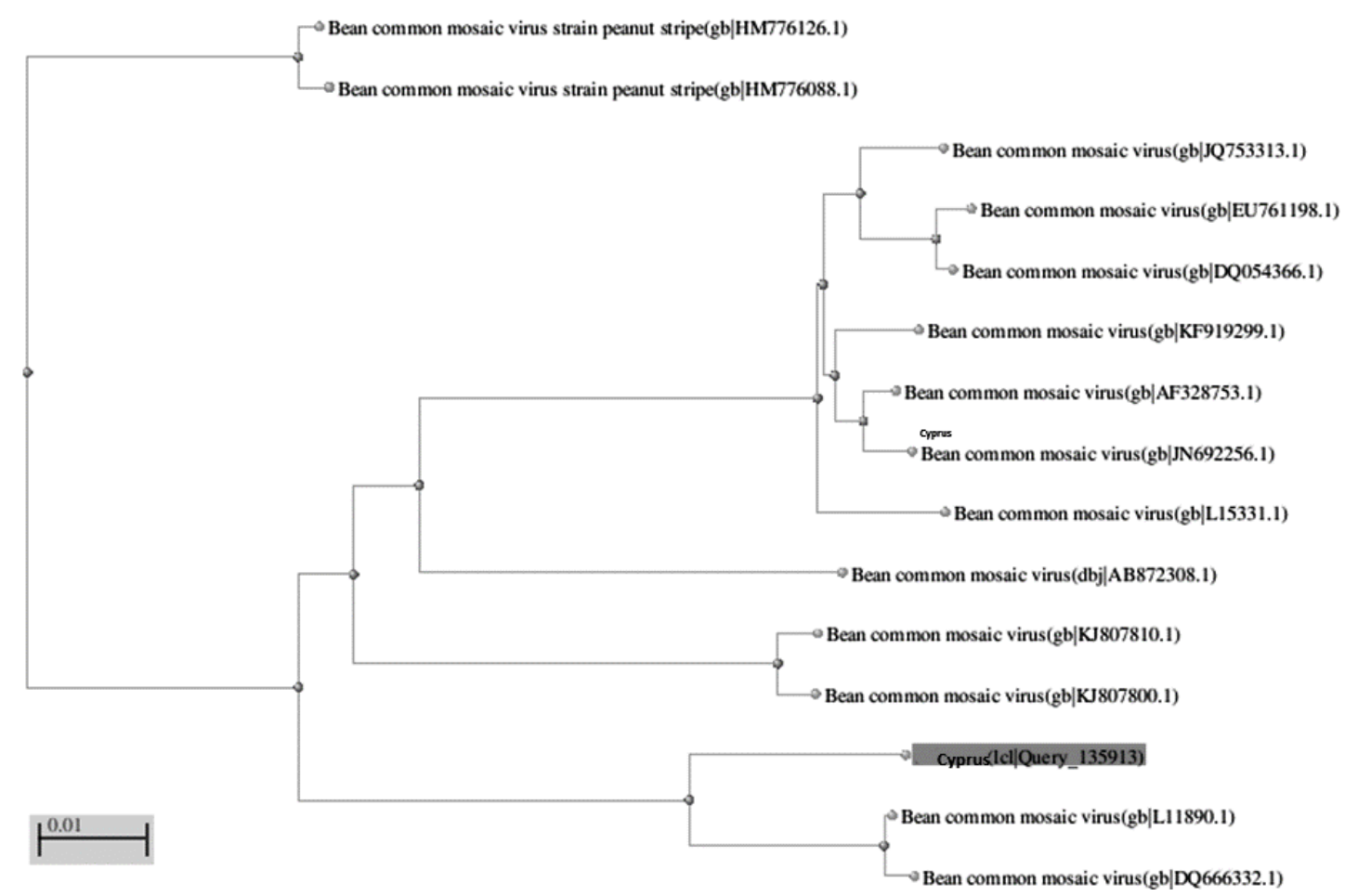

Figure 6. The family tree obtained from the data by directly sequencing PCR products. 
The fact that Cyprus is an island in the middle of the Mediterranean sea, all kind of international ships visit the island's ports, this makes it possible to exchange all plant materials from different countries. Control of plant entry and exit is not good as in all other islands; therefore, entry of diseases and pests from every country is easy. Hence, Cyprus BCMV isolate is highly similar to Mexican and Colombian isolates. The existence of Chocolate spot disease caused by the fungus Botrytis fabae which seriously hinder faba bean cultivation in the region. Investigations carried on the faba bean fields covering a total of 520.8 survey area indicating the disease prevalence in terms of infected field numbers as $82.1 \%$ and in terms of infected area as $78.2 \%$. The reason of wide coverage of the disease is that the producers being not familiar with the disease agent are unable to carry any cultural or integrated pest and disease control. The research also showed that one of the most important reasons of rapid spread and re-occurrence of the disease every year is using some of the harvested seeds for future cultivation. During the survey observations showed that infected plants are not being destroyed, increased heat and humidity resulting from insufficient aeration caused by close planting are among other reasons of rapid spread of the disease agent. For this reason we concluded that training and extension programs needed for cultivation, pest and disease control for the producers of the related regions. It is also emphasized that for the purpose of controlling this disease. Additionally cultivation related measures integrated pest and disease control in combination with others brings success. According to our research choosing disease resistant varieties, avoiding close plantation, applying crop rotation, adopting balanced fertilization, planting parallel to prevailing winds in order to provide aeration, burning infected plants and integration of efficient biopreperats (Thricoderma harzianum, Bacillus subtilis, Ampelomyces quisqualis) can increase the success, therefore they are highly recommended (El- Banoby et al., 2013; Davidson et al., 2007; Koike, 1998).

Bean common mosaic virus is the most important disease in faba bean cultivation areas at TRNC. The reason of rapid spreading of the virus in the region is thought to be pollens and seeds. Also not applying any control measures on faba been cultivation areas for Aphis fabae, the virus vector, are considered to be effective in prevalence of BCMV (Khan et al., 1993; Mink et al., 1994).

Both plant pathogens established very distinct and characteristic symptoms in plants. Simptomological appearances are highly characteristics for both pathogens. High infection rates were obtained in classical and molecular analyses. These results clearly revealed that symptomotology has great efficiency for identifying bean common mosaic virus and chocolate diseases.

In conclusion destroying infected plants, using certified seeds, efficient vector control, because of being an island efficient implementation of the quarantine rules can reduce the severity of the disease and may even erase it from the island. Various plant materials have been brought by almost every visiting sea vessel in and out of Cyprus Island which has been one of the significant points in maritime trade. The family tree created for BCMV with this research indicated that it takes place in the same group with some countries of South America. This is another significant aspect of this research which needs careful and further considerations.

\section{Kaynaklar}

Abo-Hegazy, S. R. E., El-Badawy, N.F., Mazen, M. M., Abd ElMenem, H. 2012 Evaluation of Some faba bean genotypes against chocolate spot disease using cDNA fragments of chitinase gene and some traditional methods. Asian J Agric Res, 26:60-72

Açılkgöz, S., 1984. Erzincan ve Erzurum yörelerinde Phaseolus vulgaris üzerinde virüslerin tanılanması, yayılışları ve zararları üzerinde araştırmalar. Atatürk Üniversitesi Ziraat Fakültesi (Doktora Tezi). Erzurum, s. 75.

Anonymous, 2012. Kuzey Kıbrıs Türk Cumhuriyeti Tarım ve Doğal Kaynaklar Bakanlı̆̆ı, Bitkisel Üretim Çalıştayı Sonuç Raporu (18-20 Aralık 2012), s.17.

Anonymous, 2013. Food and Agriculture Organization ofThe United Nations, web:http://faostat.fao.org.

Bhadramurthy, V., Bhat, A. I. 2009. Biological and Molecular Characterization of Bean Common Mosaic Virus Associated with Vanilla in India Indian Journal of Virology, 20(2): 70-77.

Bhat, A. I., Bhadramurthy. V., Siju, S., Hareesh, P. S. 2006. Detection and identification of Cymbidium mosaic virus infecting vanilla (Vanilla planifolia Andrews) in India based on coat protein gene sequence relationships. J. Plant Biochem. \& Biotech. 15: 3337. 
Biddle, A. J., Cattlin, N. D. 2007. Pest, Diseases and Disorders of Peas and Beans-A Colour Handbook, p. 127., Manson Pub., London.

Bora, T., Karaca, İ. 1970. Kültür Bitkilerinde Hastalığın ve Zararın Ölçülmesi, E.Ü. Matbaası, İzmir,43s

Cooper, L. I. and Jones, A.T.1983. Responses of plants to viruses: Proposals for the use of terms. Phytopathology 73, 127-128.

Davidson, J. A., Pande, S., Bretag, T. W., Lindbeck, K. D., Krishna-Kishore, G. 2007. Biology and Management of Botrytis spp. In Legume Crops.pp. 303-307. In: Botrytis: Biology, pathology and control, (Elad Y, William-son B, Tudzynski P., Delen N. ed.), Springer, Dordrecht, The Netherlands.

El-Sayed, A. S., Rania, Z. E., Ismail, A. I. 2011. Fungicidal management of chocolate spot of faba bean and assessment of yield losses due to the disease. Annals of Agricultural Science 56, 27-35

El-Banoby, F. E., Abd-AllA, M.A., Tolba, I. H., Morsy, A.A., ElGamal- Nadia, G., Khalil, M. S. A. 2013. Biological Control of Chocolate Spot Disease of Faba Bean Using some Bioagents under Field Conditions. Journal of Applied Sciences Research, 9(6): 4021. 4029.

Fidan, Ü., Yorgancl, Ü. 1990. Investigation on the detection and seed transmission of the virus diseases occurring on the pulse crops in Aegean Region. Seed transmission of virus diseases by grower seeds of artificial infected pulse crops. J. Turkish Phytopath., 19:1-6.

Gümüş, M., Erkan, S., Yorgancı, Ü., Duman, İ. 2001. Bazı sebzelerin tohumlarında bulunan viral etmenlerin saptanması üzerine araştırmalar. Türkiye IX. Fitopatoloji Kongresi (3-8 Eylül Tekirdağ): 190197.

Güzel, Ö., Arlı-Sökmen, M. 2003. Determination of some viruses infecting common bean (Phaseoulus vulgaris L.) and their incidences in seed lots in Samsun Province. J. Turk. Phytopathology. 32: 99106.

Harrison, J. G. 1988. The biology of Botrytis spp. on vicia beans and chocolate spot disease, a review. Plant Pathology 37, 168-201.

Khan, J. A., Lohuis, D., Goldbach, R., Dijkstra, J. 1993. Sequence data to settle the taxonomic position of
Bean common mosaic virus and Blackeye cowpea mosaic virus isolates. J.Gen.Virol. 74: 2243-2249.

Kılıç, H. C., Yardımcı, N. 2014. Burdur İli Bakla Üretim Alanlarında Fasulye Adi Mozayik Virüsü'nün Serolojik ve Moleküler Yöntemlerle Belirlenmesi Türk Tarım ve Doğa Bilimleri Dergisi 1(2): 289294.

Koike, S. T. 1998. Severe outbreak of chocolate spot of faba bean, caused by Botrytis fabae, in California. Plant Disease 82 (72), 83- 85.

Lısa, V., Dellavalle, G., Vaira, A. M., Morales, F. J. 1994. Bean yellow mosaic virus and other viruses in Bean in Western Asia, South-Eastern Europe and Northern China. The Bean Improvement Cooperative Annual Report, 37: 217-218,

Mink, G. I., Vetten, H. J., Ward, C.W., Berger, P. H., Morales, F. J., Myers, J. M., Silbernagel, M. J., Barnett, O. W. 1994. Taxonomy and classification of legumeinfecting potyviruses. A proposal from the Potyviridae Study Group of Plant Virus Subcommittee of ICTV. Arch.Virol. 139: 231-235.

Morgan, D. T. 1971. Numerical taxonomic studis of the genus Botrytis. Trans. Br. Mycol., Soc., 56(3): 327335.

Rahman, M. Z., Honda, Y., Islam, S.Z., Arase, S. 2002. Effect of metabolic inhibitors on red light induced resistance of broad bean (Vicia faba L.) against Botrytis cinerea. J. Phytopathol., 150: 463-468

Rhaiemi, A., Cherif, M., Kharrat, M., Cherif, M.,Harrabi, M. 2002. New faba bean genotypes resistant to chocolate spot caused by Botrytis fabae. Phytopathol. Mediterr., 41: 99-108.

Yehia, A. G. M., Mohsen, K. H. E., Magda, M. A. 2004. Influence of Some Plant Extracts and Microbioagents on Some Physiological Traits of Faba Bean Infected with Botrytis fabae. Turk J Bot 28: 519-528.

Yılmaz, M. A., Özaslan, D. 1987. Fasulye ve börülce tohumlarında afit kökenli mozayik virüsünün ELISA ile saptanması. Çukurova Üniversitesi, Ziraat Fakültesi, Bitki Koruma Bölümü, 870-873.

Yu, T. F. 1945. The red-spot disease of broad beans (Vicia faba L.) caused by Botrytis fabae Sardina in China. Phytopathology 35: 945-954. 